\title{
A controversy on HLA-G and B-cell malignancies?
}

Edgardo D. Carosella ${ }^{* *}$ and Vera Rebmann ${ }^{2}$

*Correspondence: Edgardo.carosella@cea.fr

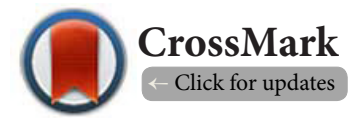

${ }^{1}$ Institute of Emerging Diseases and Innovative Therapies (iMETI), Research Division in Hematology and Immunology (SRHI), Saint-Louis Hospital, University Paris Diderot, Paris, France.

${ }^{2}$ Institute for Transfusion Medicine, University Hospital Essen, Virchowstr. 179, 45147 Essen, Germany.

\begin{abstract}
In solid tumors HLA-G is a clear immune-escape molecule inhibiting innate and adaptive effectors. This is not systematically demonstrated for B-cell malignancies, leading to a confused overall role for HLA-G in cancer likely due to the fact that malignant B-cells are as much of immune origin as the anti-tumoral effectors themselves.
\end{abstract}

Keywords: HLA-G, CLL, immune-escape, ILT2, cancer, B-cell malignancy, multiple myeloma

\section{Introduction}

The non-classical human lymphocyte antigen-G (HLA-G) is a potent suppressive molecule that impairs effector functions of immune cells belonging to the innate and the adaptive immune system. In physiological conditions HLA-G is restrictedly expressed but can be up-regulated in allogeneic situations, inflammations, and cancer [1]. HLA-G preferentially interacts with three inhibitory receptors including the immunoglobulin-like transcript (ILT) receptor-2 (LILRB1/CD85j), the ILT4 (LILRB2/CD85d), and the killer immunoglobulin-like receptor 2DL4 (KIR2DL4/CD158d) being expressed on subpopulations of T-, B-, NK-cells, or antigen presenting cells [2]. Due to the functionality of receptors and their expression profile, HLA-G is involved in immune tolerance mechanisms. It is well established that tumors express HLA-G including hematological tumors. In solid tumors the function of HLA-G is clearly that of an immune-escape-mediating molecule acting for the benefit of the tumor resulting in a worse clinical outcome. Thus, HLA-G expression is associated to a bad prognosis [3]. But this was not systematically demonstrated for non-solid tumors, leading to a confused overall role for HLA-G in cancer. The purpose of this point of view is to clear up this situation.

In hematological tumors especially for B-cell malignancies, studies yielded three types of results: (i) HLA-G expression is related to a bad prognosis, (ii) HLA-G is deemed irrelevant to prognosis, or (iii) according to the demonstrative data shown, HLA-G expression should be related to a good prognosis.

First situation: HLA-G expression is related to worse prognosis Similar as for solid tumors HLA-G expression on B-cell chronic lymphocytic leukemia (B-CLL) cells was associated with shorter survival in two studies $[\mathbf{4 , 5}]$. One of them identified HLA-G as an independent prognostic factor for disease progression and associated HLA-G bearing tumor cells with low lgG levels and low T- and NK-cell counts [4]. Very recently, it was evidenced that the HLA-G expression on B-CLLs was associated to a homozygous deletion of 14 base pairs within the 3 '-untranslated region of $H L A-G$ gene being related to stable $m R N A$ and protein expression. Patients having this genotype revealed a reduced overall survival [6]. Here, HLA-G expression correlated with the number of regulatory T-cells (Tregs) [6] and is involved in the protection of B-CLL cells from NK-mediated killing $[6,7]$. In multiple myeloma (MM) HLA-G expression on malignant plasma cells was also associated with a poor prognosis [8]. Interestingly, HLA-G was frequently acquired by T-cells from malignant plasma cells through a mechanism of membrane transfer. These HLA-G positive T-cells harbored regulatory potential similar to Tregs. HLA-G surface-expression on acute lymphoblastic leukemia is positively correlated with peripheral and bone marrow (BM) blast cells, but negatively with NK-cell counts suggesting its importance in tumor escape [9].

Second situation: HLA-G expression is of irrelevant prognosis Other studies revealed either a low HLA-G expression on B-CLL cells in the majority of cases $[10,11]$ or increased soluble HLA-G levels in B-CLL [12], B-non-Hodgkin lymphomas [12], and MM patients $[13,14]$ without any clinical association.

\section{Third situation: HLA-G expression should be of good prognosis}

HLA-G expression should be of good prognosis if tumor cells express $\mathrm{HLA}-\mathrm{G}$ receptors, as it is the case for B-cell malignancies 
and ILT2. Indeed, the interaction of HLA-G and ILT2 leads to proliferation inhibition of the ILT2-bearing cell, which was shown for T-cells $[4,5]$ and ILT2 positive B-cell lines, MM cells, $B-C L L$ cell lines and other malignant cells [15]. A recent paper demonstrated the same capability for a beta- 2 microglobulinfree (b2m-free) soluble synthetic HLA-G constructs interacting with other receptors than ILT2 [16]. Taken together these data imply that HLA-G should be correlated with a good prognosis by blocking the proliferation of tumor cells harboring HLA-G specific receptors.

How to explain these apparently antagonist/mutually exclusive effects?

The likeliest explanations for the antagonist/mutually exclusive effects of HLA-G on B-cell malignancies are (i) differences in ILT2 expression and function by tumor cells, (ii) differences in HLA-G structural conformations and their interactions with receptors, and (iii) the impact of HLA-G expression on chemotherapy.

\section{Differences in ILT2 expression and function by tumor cells}

It is known that ILT2 is expressed with cell-specific patterns and cell-surface densities. The ILT2 expression on B-cells depends on their maturation stage: developing B-cells in BM acquire ILT2 during maturation; early transitional B-cells in the process of final maturation after leaving BM, express ILT2 in a lower frequency than late transitional B-cells; other peripheral B-cell populations ubiquitously express ILT2 [17]. Thus, ILT2 expression levels for malignant B-cells may depend on the compartment in which they exist, and whether they have completed the maturation process.

B-CLL cells are present in blood, secondary lymphatic tissues and BM. Peripheral B-CLL cells express ILT2. They are non-dividing resting $B$-cells, which accumulate in the blood due to resistance to apoptosis. In this context, HLA-G expression would contribute to the accumulation of malignant cells by impairing T- and NK-cell functions. Unlike peripheral cells, tissue CLL cells proliferate at a relatively high rate in so-called micro-anatomical proliferation centers or pseudofollicles. There is no data on HLA-G or ILT2 expression by tissue CLL. However, if tissue CLL cells express HLA-G but not ILT2, HLA-G would inhibit T- or NK-cells exactly as evidenced recently $[6,7]$. In this configuration, the overall effect of HLA-G would indeed impair the anti-tumor response, and a correlation between HLA-G presence and bad prognosis would be observed.

Unfortunately, this explanation does not apply to MM. The majority of MM cells remain in the BM, while survival, growth and proliferation are supported by micro-environmental factors of BM niches, and only a small number of tumor cells continuously circulate in the blood. Moreover, MM are transformed terminally maturated B-cells and as such expressed ILT2 in BM and blood. However, despite this ILT2 expression, there are discrepancies in the reports on the function of HLA-G on MM, ranging from "indicative of bad prognosis" [8] to "irrelevant to prognosis" $[13,14]$. This indicates that ILT2 expression is not sufficient to explain the data discrepancies observed for the function of HLA-G on B-cell malignancies.

\section{Differences in HLA-G structural conformations and their interactions with receptors}

HLA-G can exist in various structural conformations [18]: besides the seven monomeric HLA-G molecules (HLA-G1 HLA-G7), which are either b2m-free or b2m-associated, all isoforms can additionally form disulfide-linked dimers [19]. The monomeric/dimeric status of HLA-G is of paramount importance for its function because HLA-G dimers bind ILT2 with a superior avidity than HLA-G monomers do [19]. Thus, the supply of dimers may regulate the signaling potential by the ILT2 receptor.

As the monomeric/dimeric status of HLA-G is unknown in $B$-cell malignancies, the differences in prognostic appraisal might be explained by that HLA-G from B-cell malignancies is not always dimeric. This begs the question of how and under which conditions HLA-G molecules form dimers. If HLA-G molecules spontaneously form dimers, it should be present in all B-cell malignancies. However, dimerization appears not to be an exclusive spontaneous process and might be regulated by intrinsic or extrinsic factors such as micro-environmental factors [20].

Moreover, the existence of active alternate HLA-G structures others than the detected b2m-associated ones would prevent an accurate correlation to clinical outcome and confuse the results highlighting the need for studies defining the most relevant HLA-G structures and its cognate receptor interactions in vivo.

\section{Impact of HLA-G expression on chemotherapy}

Therapy of B-cell malignancies may vary in different studies and that may impact the overall conclusions: the treatment of the patient as an extrinsic factor might vary between centers and this might account for inter-study differences observed, but the impact of chemotherapeutic agents on HLA-G expression and/or function is not our point here. Rather, the question is whether or not HLA-G does interfere with chemotherapeutic agents. If HLA-G inhibits malignant B-cell proliferation as data show, this would also shield tumor cells from chemotherapeutic drugs, whose effectiveness depends on tumor cell proliferation, and the resulting outcome would then depend on the sensitivity of the tumor cells towards both HLA-G and therapy. Thus, HLA-G might decrease treatment effectiveness and so eventually translate into bad prognosis. It is therefore possible that all results obtained so far are correct and that the balance between the effect of HLA-G and that of other treatments counts.

\section{Conclusions}

It is well established that HLA-G expression by solid tumors 
inhibits the effectors of the anti-tumor immunity and constitutes an immune-escape mechanism. However, this holds only partially true for non-solid tumors, especially B-cells malignancies. As shown for B-CLL and ALL, HLA-G may protect the tumor cells by blocking immune effectors, decreasing the absolute T- and NK-cell counts or inducing Treg. For therapeutic intervention, patients with B-cell malignancies would benefit from a blocking of HLA-G functions to restore anti-tumor immunity, as recently demonstrated [7]. For other B-cell malignancies, however, HLA-G expression does not directly correlate with worse prognosis. This could be linked to a HLA-G cytostatic effect on tumor cells and the result of the balance between this beneficial effect, its consequences for proliferation-based therapies, and the anti-tumor immunity inhibition effect. Obviously, more studies are required to understand this balance and its underlying mechanisms.

\section{List of abbreviations}

HLA-G: Human lymphocyte antigen-G

ILT2: Immunoglobulin-like transcript receptor-2

ILT4: Immunoglobulin-like transcript receptor-4

CLL: Chronic lymphocytic leukemia

Treg: Regulatory T-cells

MM: Multiple Myeloma

$\mathrm{BM}$ : Bone marrow

B2m: Beta-2 microglobulin

ALL: Acute lymphocytic leukemia

\section{Competing interests}

The authors declare that they have no competing interests.

\section{Authors' contributions}

\begin{tabular}{|l|c|c|}
\hline Authors' contributions & EDC & VR \\
\hline Research concept and design & $\checkmark$ & $\checkmark$ \\
\hline Collection and/or assembly of data & -- & -- \\
\hline Data analysis and interpretation & -- & -- \\
\hline Writing the article & $\checkmark$ & $\checkmark$ \\
\hline Critical revision of the article & $\checkmark$ & $\checkmark$ \\
\hline Final approval of article & $\checkmark$ & $\checkmark$ \\
\hline Statistical analysis & -- & -- \\
\hline
\end{tabular}

\section{Acknowledgement}

This work was supported by IFORES (D/107-81080), University of Duisburg-Essen, and by Deutsche Krebshilfe (109816).

\section{Publication history}

EIC: Howard L. Kaufman, Rush University Medical Center, USA. Received: 20-May-2016 Final Revised: 15-Jun-2016

Accepted: 05-Jul-2016 Published: 12-Jul-2016

\section{References}

1. Carosella ED, Moreau P, Lemaoult J and Rouas-Freiss N. HLA-G: from biology to clinical benefits. Trends Immunol. 2008; 29:125-32. | Article I PubMed

2. Carosella ED, HoWangYin KY, Favier B and LeMaoult J. HLA-G-dependent suppressor cells: Diverse by nature, function, and significance. Hum Immunol. 2008; 69:700-7. | Article | PubMed

3. Gonzalez A, Rebmann V, LeMaoult J, Horn PA, Carosella ED and Alegre E. The immunosuppressive molecule HLA-G and its clinical implications.
Crit Rev Clin Lab Sci. 2012; 49:63-84. I Article I PubMed

4. Nuckel H, Rebmann V, Durig J, Duhrsen U and Grosse-Wilde H. HLA-G expression is associated with an unfavorable outcome and immunodeficiency in chronic lymphocytic leukemia. Blood. 2005; 105:1694-8. | Article | PubMed

5. Erikci AA, Karagoz B, Ozyurt M, Ozturk A, Kilic S and Bilgi O. HLA-G expression in $B$ chronic lymphocytic leukemia: a new prognostic marker? Hematology. 2009; 14:101-5. | Article | PubMed

6. Rizzo R, Audrito V, Vacca P, Rossi D, Brusa D, Stignani M, Bortolotti D, D’Arena G, Coscia M, Laurenti L, Forconi F, Gaidano G, Mingari MC, Moretta L, Malavasi F and Deaglio S. HLA-G is a component of the chronic lymphocytic leukemia escape repertoire to generate immune suppression: impact of the HLA-G 14 base pair (rs66554220) polymorphism. Haematologica. 2014; 99:888-96. | Article I PubMed Abstract | PubMed FullText

7. Maki G, Hayes GM, Naji A, Tyler T, Carosella ED, Rouas-Freiss N and Gregory SA. NK resistance of tumor cells from multiple myeloma and chronic lymphocytic leukemia patients: implication of HLA-G. Leukemia. 2008; 22:998-1006. | Article | PubMed

8. Brown R, Kabani K, Favaloro J, Yang S, Ho PJ, Gibson J, Fromm P, Suen H, Woodland N, Nassif N, Hart D and Joshua D. CD86+ or HLA-G+ can be transferred via trogocytosis from myeloma cells to $\mathrm{T}$ cells and are associated with poor prognosis. Blood. 2012; 120:2055-63. | Article | PubMed

9. Alkhouly N, Shehata I, Ahmed MB, Shehata H, Hassan S and Ibrahim T. HLA-G expression in acute lymphoblastic leukemia: a significant prognostic tumor biomarker. Med Oncol. 2013; 30:460. | Article | PubMed

10. Giannopoulos K, Dmoszynska A, Bojarska-Junak A, Schmitt M and Rolinski J. Expression of HLA-G in patients with B-cell chronic lymphocytic leukemia (B-CLL). Folia Histochem Cytobiol. 2008; 46:457-60. | Article | PubMed

11. Perez-Chacon G, Rosado S, Rebolleda N, Losada-Fernandez I, Vargas JA, Morado M, Jorda J and Perez-Aciego P. Prognostic irrelevance of HLA-G in B-cell chronic lymphocytic leukemia. Int J Lab Hematol. 2009; 31:32737. | Article | PubMed

12. Sebti Y, Le Maux A, Gros F, De Guibert S, Pangault C, Rouas-Freiss N, Bernard $\mathrm{M}$ and Amiot $\mathrm{L}$. Expression of functional soluble human leucocyte antigen-G molecules in lymphoproliferative disorders. $\mathrm{Br} \mathrm{J}$ Haematol. 2007; 138:202-12. | Article I PubMed

13. Leleu X, Le Friec G, Facon T, Amiot L, Fauchet R, Hennache B, Coiteux V, Yakoub-Agha I, Dubucquoi S, Avet-Loiseau H, Mathiot C, Bataille R and Mary JY. Total soluble HLA class I and soluble HLA-G in multiple myeloma and monoclonal gammopathy of undetermined significance. Clin Cancer Res. 2005; 11:7297-303. I Article I PubMed

14. Wlasiuk P, Stec A, Piechnik A, Kaminska W, Dmoszynska A, Ksiazek A and Giannopoulos K. Expression of soluble HLA-G in multiple myeloma patients and patients with renal failure. Leuk Res. 2012; 36:881-3. I Article I PubMed

15. Naji A, Menier C, Maki G, Carosella ED and Rouas-Freiss N. Neoplastic B-cell growth is impaired by HLA-G/ILT2 interaction. Leukemia. 2012; 26:1889-92. | Article | PubMed

16. LeMaoult J, Daouya M, Wu J, Loustau M, Horuzsko A and Carosella ED. Synthetic HLA-G proteins for therapeutic use in transplantation. FASEB J. 2013; 27:3643-51. | Article | PubMed Abstract | PubMed FullText

17. Banham AH, Colonna M, Cella M, Micklem KJ, Pulford K, Willis AC and Mason DY. Identification of the CD85 antigen as ILT2, an inhibitory MHC class I receptor of the immunoglobulin superfamily. J Leukoc Biol. 1999; 65:841-5. | Article | PubMed

18. Paul P, Cabestre FA, Ibrahim EC, Lefebvre S, Khalil-Daher I, Vazeux G, Quiles RM, Bermond F, Dausset J and Carosella ED. Identification of HLA-G7 as a new splice variant of the HLA-G mRNA and expression of soluble HLA-G5, -G6, and -G7 transcripts in human transfected cells. Hum Immunol. 2000; 61:1138-49. | Article I PubMed

19. Shiroishi M, Kuroki K, Ose T, Rasubala L, Shiratori I, Arase H, Tsumoto K, Kumagai I, Kohda D and Maenaka K. Efficient leukocyte Ig-like receptor 
Carosella et al. Journal of Immunotherapy Applications 2016,

http://www.hoajonline.com/journals/pdf/2055-2394-3-1.pdf

signaling and crystal structure of disulfide-linked HLA-G dimer. J Biol

Chem. 2006; 281:10439-47. | Article | PubMed

20. Zilberman S, Schenowitz C, Agaugue S, Benoit F, Riteau B, Rouzier R, Carosella ED, Rouas-Freiss N and Menier C. HLA-G1 and HLA-G5 active dimers are present in malignant cells and effusions: the influence of the tumor microenvironment. Eur J Immunol. 2012; 42:1599-608. | Article | PubMed

\section{Citation:}

Carosella ED and Rebmann V. A controversy on

HLA-G and B-cell malignancies? J Immunother Appl. 2016; 3:1. http://dx.doi.org/10.7243/2055-2394-3-1 